\title{
Development of Communication and Speech Skills of Students in the Process of Education
}

\author{
Liza Naviy,\#,", Gulsara G. Zhussupbekova ${ }^{2, \#}$, Nina M. Stukalenko ${ }^{3, \#}$, Bariya B. Zhakhina ${ }^{1, \#,}$ \\ Lazzat S. Baimanova ${ }^{1, \#}$ and Asiya K. Kukubaeva ${ }^{4, \#}$ \\ ${ }^{1}$ Sh. Ualikhanov Kokshetau State University, Kokshetau, Republic of Kazakhstan \\ ${ }^{2}$ Kazakh National Pedagogical University Named after Abai, Almaty, Republic of Kazakhstan \\ ${ }^{3}$ Institute of Professional Development of the Pedagogical Workers in Akmola Region, Branch of JSC \\ "National Center for Professional Development "Orleu"', Kokshetau, Republic of Kazakhstan \\ ${ }^{4}$ Kokshetau University of A. Myrzakhmetov, Kokshetau, Republic of Kazakhstan
}

\begin{abstract}
The article aims to study and diagnose school students with disabilities' levels of communication and speech skills development. Communication technologies in the process of forming communicative competence will contribute to the successful implementation of correctional work, if necessary, an individual or adapted educational program for students with disabilities. During the conduction of the study, the authors used the following types of methods: analysis, synthesis, modelling, observation, survey-statistical method analysis of the data allowed to differentiate levels of communication and speech skills development. The authors revealed the most effective forms and methods of work at the literature levels. The scientific-methodical and practical aspects of the application of communication technologies for the development of school students with disabilities' speech activities were generalized. In modern education, it has been substantiated that communication technologies are used as a means of communication skills formation and as a means of activation of the students' cognitive work. Based on the theoretical analysis of the investigated problem and the experimental work results, the authors have formulated the generalizing positions. It was concluded that the solution to the investigation of the school students with disabilities' speech activities development problem is possible at smart scientific and methodological use of communication technologies.
\end{abstract}

Keywords: Communication competence, educational-cognitive process, communication learning technologies, diagnostics, grammar standards.

\section{INTRODUCTION}

Modern pedagogical science has accumulated the experience of scientific research devoted to the relevant problems of education and upbringing, including the development of the school students' speech activities by means of cutting-edge educational technologies [1-3]. This includes applying the psychological and pedagogical methodological systems, ensuring the development of the brand-new integrated guidance [4-9]. At the present stage of social development, changes are occurring in the education system. The main focus at the moment is the introduction of inclusive education. It involves the organization of such an educational environment where students with disabilities can receive education together with other students. Inclusive education aims to develop the personality of a student with disabilities and facilitate their social adaptation.

A student with disabilities is an individual who has physical and/or psychological developmental

\footnotetext{
*Address correspondence to this author at the Sh. Ualikhanov Kokshetau State University, Kokshetau, Republic of Kazakhstan; Tel: +731622255583;

E-mail: naviy3745-1@kpi.com.de

"These authors are equally contributed.
}

deficiencies, is confirmed by the psychological, medical, and pedagogical commission, and prevents education without creating special conditions. In terms of composition, the category of students with disabilities is heterogeneous, determined by various disorders present in children of this group. The range of differences in the development of children with disabilities is extensive: from relatively normally developing students who experience temporary or easily overcome learning difficulties to students with multiple disabilities due to severe damage to the central nervous system. One child can study together with healthy children with properly organized psychological and pedagogical support. Another can only study according to an adapted educational program or a particular individual development program.

Teaching the language disciplines implies the use of communication learning technologies aimed at the student's complete immersion into the educational process. In the teaching process, one should be focused on the interpersonal interaction of the educational and upbringing process and the humanization of the pedagogical influence. The communication technologies of education are based on the following: the practical focus of the language 
learning; communication and speech base of the educational process; complex organization of the language material; differentiated approach towards teaching; and comprehensive intensification of the educational process. The essence of the education based on the application of the communication technologies is concluded in creating the conditions for the formation of active cognitive activities of the students. The leading idea is the idea of the formation of the school student's skill to join in the educational activities as a subject, the capacity of cooperation, and to manifest communication abilities. Thus, in the education and upbringing process, communication technologies are used as both a means of forming communication and speech skills and a means of activating the students' educational-cognitive activities.

Formed in elementary school, communicative competence becomes the basis of communicative universal educational actions in secondary and basic schools. Schoolchildren use communication skills in various situations. This skill requires the ability to assess communication conditions adequately. Important is the ability to determine the purpose, form, means of communication, regulate it, correctly express feelings, attitude to the content of the communication, and the participants in communication. So, the purpose of the article is to study and diagnostic of school students with disabilities' levels of communication and speech skills development.

\section{MATERIALS AND METHODS}

Experimental work at the level of the school students with disabilities' communication and speech skills development was conducted. The study was conducted from January to April 2019. The sample size was 170 subjects: 83 boys and 87 girls. The block of special questions was aimed at identifying the typical psychological behaviour of the respondent. This research is conducted by the authors' team on a collegiate basis, by creating a vast experimental site on the premises of the Abai Kazakh National Pedagogical University (Almaty), Sh. Ualikhanov Kokshetau State University and Myrzakhmetov Kokshetau University.

During the conduction of the study, the authors used the following types of methods: analysis, synthesis, modelling, observation, survey. The observational experiment was aimed at diagnosing the current state of the mental development of schoolchildren. The formative stage was aimed at studying the psychological and pedagogical phenomenon directly in the process of specially organized experimental training. The control experiment's purpose was to process and analyse the results-statistical analysis of the data allowed to differentiate levels of communication and speech skills development.

In the course of the research, the authors have revealed the most effective forms and methods of work at the language-related lessons: the work with the word from many aspects, implying the reference to various vocabularies and kinds of analysis; analysis and selection of the associative fields to the considered word; creation of decorative and expressive means on its basis; creation of the context for the word, etc.; innovation approaches towards the work with the vocabulary: dictations, self-dictations, etc.

All procedures performed in studies involving human participants were according to the institutional and national research committee's ethical standards and with the 1964 Helsinki declaration and its later amendments or comparable ethical standards. The study was approved by the National Ethics Commission of the Ministry of Health of the Republic of Kazakhstan on October 23, 2019, No 1823-A.

\section{RESULTS}

Difficulties in the formation of communicative competencies determine the special educational needs of students with disabilities, unique methods for the formation of effective speech communication, and the selection of adequate ways to achieve educational goals. In this regard, the teacher's ability to model speech situations, choose an adequate speech form, and create conditions for students that are close to real is of particular importance. Adequate use of these competencies allows the teacher to achieve the necessary educational results.

It is important to have effective listening skills. The teacher must constantly improve his level of verbal and communicative competence. In communication with students, it is necessary to alternate dialogue strategies of interaction and monological impact. When planning a lesson, it is useful to think through speech methods and forms of expressing an emotional attitude to content and students. During the lesson, it is necessary to achieve not only cognitive, educational, and correctional development goals but also a communicative goal. 
The main tasks for the formation of communicative competence of students with disabilities are:

- the development of oral and written language;

- $\quad$ prevention and correction of reading and writing disorders due to speech impairment;

- $\quad$ prevention and correction of reading and writing due to lack of visual functions;

- the formation and correction of the semantic component of reading;

- accumulation of experience of effective interaction with other people;

- $\quad$ the formation of the ability to overcome current life problems, using verbal and non-verbal communication as a means of achieving the goal;

- to form the ability to conduct a conversation, formulate a question, express a personal position, a request, give advice;

- to develop the ability to express correctly, disagree, show sympathy and appreciation, and master the traditional cultural, social and normative forms of expressing your emotions;
- to form the ability to transmit or use the information received in the process of communicative interaction;

- to expand (individually-dosed) the range of communicative-speech situations in extracurricular activities, outside educational institutions (excursions, theaters, museums, circles, sections).

The requirements imposed on the communication competence imply oral (discussions, reports, and presentations) and written (reading, understanding, and writing of various texts) communication forms. Communication competence develops such an important personal trait as people skills. People skills are understood as an individual's capacity to establish contacts easily and by his/her own initiative in any sphere of communication, as well as competence in supporting the contacts. People's skills reflect not only the psychological type of the individual but also his/her social experience of communication, implying the focus on the partner - the ability to listen to and correct his/her own speech behavior in due time.

The average age of participants was 8 years. In terms of gender girls prevailed (87 of respondents), 83 of respondents were boys, as shown in Table 1. All

Table 1: Age and Gender Structure of School Students with Communication Disabilities

\begin{tabular}{|c|c|c|c|c|}
\hline \multirow{2}{*}{ Age, years } & \multicolumn{3}{|c|}{ Gender } \\
\cline { 2 - 5 } & \multicolumn{2}{|c|}{ Male } & \multicolumn{3}{c|}{ Female } \\
\cline { 2 - 5 } & Abs. & Rel., $\%$ & Abs. & 32.1 \\
\hline \hline 6 & 24 & 28.9 & 31 & 29.1 \\
\hline 7 & 17 & 20.4 & 16 & 18.1 \\
\hline 8 & 8 & 9.6 & 8 & 8.6 \\
\hline 9 & 19 & 22.8 & 9 & 12.1 \\
\hline 10 & 15 & 18.3 & 87 & 100 \\
\hline
\end{tabular}

Table 2: Diagnostic Results of the School Students with Disabilities' Levels of Communication and Speech Skills Development by Means of Communication Learning Technologies

\begin{tabular}{|c|c|c|}
\hline $\begin{array}{c}\text { Levels of communication and } \\
\text { speech skills development }\end{array}$ & Performance before the experiment & Performance after the experiment \\
\hline \hline Low & $49.3 \%$ & $10.2 \%$ \\
\hline Middle & $31.6 \%$ & $52.6 \%$ \\
\hline High & $19.1 \%$ & $37.2 \%$ \\
\hline
\end{tabular}


participants were school students with communication disabilities.

In the course of studying elementary school students with disabilities' communication and speech skills development using the communication technologies and other active organizational forms of education, the authors studied their dynamics under the influence of these technologies. The obtained data are presented in Table $\mathbf{2}$.

The authors revealed the most effective forms and methods of work at the literature levels: the work with the text from many aspects, analysis of the artistic form of the writings, the work under vocabulary; exposition (analytical, reduced, and commented); creation of the context to the figurative means; comparative analysis of the literary texts; various kinds of essays and their qualitative analysis (essays based on the observations, a literary text, a picture, a play, a movie, the motives of musical compositions, etc.), stylized compositions (fable, fairytale, topical satire, own-made stories, etc.); versification; role-plays and speech improvisations; preparation and protection of the literary projects; preparation and presentation of literature research works; assistance in the preparation of the teacher's lecture; creation of the script, role-playing of the literary text's pieces, etc. Besides, the communication technology may also be actively used at the organization of extra-curricular activities: work in sections; literature excursions; visits to the theatres with the subsequent discussion of the plays; reading conferences, discussions, disputes, literature meetings, staging the performances based on the pieces of literature, etc. (Figure 1).

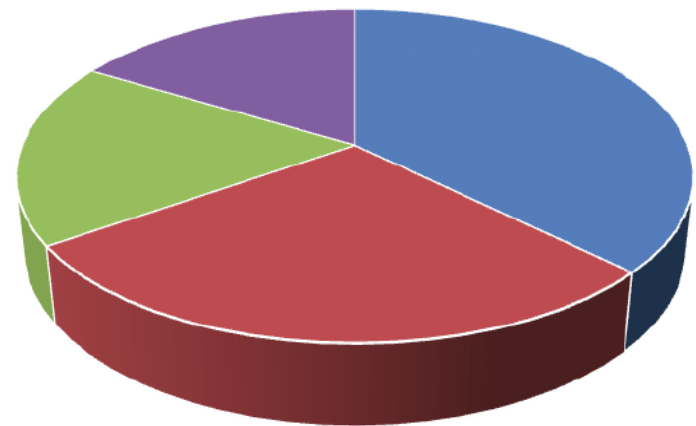

- the work with the word from many aspects

- innovation approaches towards the work with the vocabulary

analysis and selection of the associative fields to the considered word

Figure 1: The most effective forms and methods of work at the language-related lessons.
The obtained data show that the level of school students with disabilities' communication and speech skills development has been significantly improved under the influence of communication learning technologies. Thus, the analysis of the conducted experimental work has demonstrated their actual effectiveness.

The results of the conducted study were discussed during the meetings of those departments, the scientific seminar "Actual Problems of Psychological and Pedagogic Science and Modern Education" and on the international scientific and practical conferences: "Valikhanov's Readings" (Kokshetau), "Current Problems of Contemporary Education and Pedagogic Specialists Training" in Kazakhstan (Almaty), "Introducing New Educational Technologies and Principles of Educational Process Organization" (Singapore), "Modern Education: Problems and Solutions" (Thailand), "Education and Science without Borders" (Germany), "Current Problems of Science and Education" (Russia), "Problems of International Integration of National Education Standards" (France). The generalized results of the conducted study are being published for the first time.

\section{DISCUSSION}

Communication technology is based on the interconnected integrated education of all kinds of speech activities: listening, speaking, reading, and writing. An essential element of the educational communication technologies is the contents of the speech behavior, which consists of the awareness of the speech situation and the speech acts [10,11]. The main goal of applying the communication technologies is the development of the students' ability to solve the communication tasks within the educational, labor, routine, cultural, and public spheres of communication using the minimum of the vocabulary and grammar they actively possess [12]. The educational tasks, the solution of which is necessary for the achievement of these tasks is concluded, in the formation among the school students are the abilities and skills to feel free at expressing their own and understanding other people's thoughts in oral and written form, formation of the need for constant development of their vocabulary, in developing the skills to use the studied grammar structures in the speech, in ensuring the comprehension of the standards (orthographic, lexical and grammar) of the literature language, and in the development of the skill of structuring and assessing their speaking $[13,14]$. 
The conducted research allowed generalizing the scientific-methodical and practical aspects of the application of communication technologies for the development of school students with disabilities' speech activities. The communication technology implies the functionality of education (activities of the student): the student asks, confirms the thought, encourages his/her interlocutor to act by means of questions, disputable statements, etc., expresses doubts and in the course of this analyzes the grammar standards [15-18]. At the same time, the situation's novelty should be ensured: a new speech task, a new interlocutor, and a new subject for the discussion. The main ways of acquiring the communication competence are various kinds of activities because exactly the activities provide the awareness of the need for communication, the need for the use of speech, and formation of the ideas of the speech behavior [19, 20]. The most important unit of the educational process using communication technologies is the communication situation. By creating the communication situation, the system of the interaction between the interlocutors is established: the communication is motivated, the speech material is provided, the speech skills are acquired, the activity and independence of the communication are developed, as well as the communication skills of the students with disabilities are enhanced.

Thus, the lessons with an application of the communication technologies allow teaching the school students with disabilities, the language as a means of communication, world cognition and their place in the world, belonging to the culture, provide an opportunity of developing their skill of active, creative, and literate acquisition by all the kinds of speech activities.

\section{CONCLUSIONS}

As the investigation of the school students with disabilities' speech activities development problem has shown, the solution to this problem is possible at smart scientific and methodological use of the communication technologies, which are the most adequate to the set task. These educational technologies not only contribute to the development of the elementary school students with disabilities' speech activities development, but also help them to take an active part in the educational process, to take responsibility for the enrichment of their knowledge and development of the skills, to analyze relevant problems, to synthesize the knowledge, to effectively work in a team, to be able to write persuasive speeches and to acquire the skills of presentation, to make comprehensive decisions, and to develop self-confidence. The main tasks for the formation of communicative competence of students with disabilities were highlighted.

Besides, the result of using the communication technologies is the harmonious development of all the communication skills of the students, their speech, listening comprehension, reading, writing, and analytical processing of the information; overcoming the fear of public speech; feeling free in real communicative situations; development of the vocabulary; reception and application of the new information in the sphere of science, education and communications.

\section{ACKNOWLEDGEMENT}

None.

\section{REFERENCES}

[1] Bespalko VP. The components of pedagogical technologies Moscow: Enlightenment 2002.

[2] Kukushin VS. Pedagogical technologies. Moscow: March 2004.

[3] Selevko GK. Modern educational technologies. Moscow: Public Education 2000.

[4] Gershunskiy B. Philosophy of education for the xxi century. Moscow: Nauka 2001

[5] Lvov MR. Speech of junior pupils and ways for its development. Moscow: Prosveshcheniye 2001.

[6] Ramzayeva TG. Methodic fundamentals of language education and literary development of junior pupils. St. Peterburg: Prospect 2001

[7] Bystrova YeA. Communicative approach to native language teaching. Moscow: Nauka 2006.

[8] Politova NI. Speech development of junior pupils at Russian language lessons. Moscow: Prosveshchenie 2004.

[9] Ligay MA, Ermekova ZhK, Stukalenko NM. The most important priorities of the educational policy of the Republic of Kazakhstan and possible ways of implementation. International Journal of Experimental Education 2015; 1 : 715-718.

[10] Shcherba LV. Pedagogical technology in the context of educational technology. Moscow: Nauka 2001.

[11] Slobin DA. Psycholinguistics. Moscow: Prosveshcheniye 2009.

[12] Kolshanskiy GV. Communicative function and language structure. Moscow: Nauka 2004

[13] Likhachev BT. Pedagogics: series of lectures. Training manual of students-teachers, educational institutions and listeners of IPK and FPK. Moscow: Urait-M 2001.

[14] Volkov IP. Modern educational technologies. Moscow: Pedagogics 2008.

[15] Monakhov VM. Fundamentals of pedagogical technology. Moscow: Prosveshcheniye 2007.

[16] Skatkin MI. Modern didactics: theory and practice. Moscow: Prosveshcheniye 2005. 
[17] Klarin MV. Technologies of teaching: the ideal and reality. Riga: Vesta 2000

[18] Stukalenko NM, Anishchenko OA, Turtkarajeva GB, Shajakhmetova AA, Ermekova ZK. About preparation of future teachers for application of innovative study technologies. Life Science Journal 2013; 12: 131-133.
[19] Passov Yel. Communicative teaching technology. Moscow: Nauka 2010.

[20] Zimnyaya I. Core competencies are a new paradigm of the result of modern education. Moscow: Akademiya 2001.

Received on 25-07-2020

Accepted on 18-08-2020

Published on 14-09-2020

DOI: https://doi.org/10.6000/2292-2598.2020.08.03.21

(C) 2020 Naviy et al.; Licensee Lifescience Global.

This is an open access article licensed under the terms of the Creative Commons Attribution Non-Commercial License (http://creativecommons.org/licenses/by-nc/3.0/) which permits unrestricted, non-commercial use, distribution and reproduction in any medium, provided the work is properly cited. 